\title{
The life history of Loligo vulgaris and Loligo forbesi (Cephalopoda: Loliginidae) in Galician waters (NW Spain)
}

Angel Guerra*, Francisco Rocha

Instituto de Investigaciones Marinas (CSIC), Eduardo Cabello No. 6, 36208 Vigo, Spain

* Corresponding author.

Abstract

The population biology of Loligo vulgaris and Loligo forbesi in Galician waters is described based on monthly samples from the fishery obtained during the period February 1991-June 1992. Maturity was assessed using a maturity scale and indices. The estimated number of oocytes in mature females varied from 782 to 21885 in L. vulgaris and from 1317 to 14956 in L. forbesi, and showed a slight positive correlation with the length of the mantle (ML) for both species. Oocytes in the ovaries fall into three discrete size classes, which suggests that L. vulgaris and L. forbesi are intermittent or multiple spawning species. In L. vulgaris males mature at two different modal sizes, hence perhaps at two different ages, while in L. forbesi this occurs in both males and females. Males mature earlier in the season than females in both species. The maximum number of spermatophores found was 1010 and 1000 in two L. vulgaris males with 119 $\mathrm{mm}$ and $400 \mathrm{~mm}$ ML respectively, and 1035 in a L. forbesi male with $150 \mathrm{~mm}$ ML. In both species, spermatophore length increases with ML. Loligo forbesi males maturing at a larger size produce fewer but larger spermatophores than those maturing at a small size. Loligo vulgaris spawn throughout the year, but the period of more intensive spawning extends from December to April. The breeding season of L. forbesi extends from December to May, the more intensive spawning extending from December to February. Sex ratios were variable for both species. Age and growth for both species and sexes were estimated by examining growth increments in the statoliths. Like-sized individuals had different ages in both species. The life span of L. vulgaris was estimated at about $l$ year while L. forbesi seems to reach an age of 15-16 months. A list of prey species found in gastric contents of both species is given. The diet of L. vulgaris comprises fish (86.8\%), cephalopods (6.0\%), crustaceans (3.0\%) and polychaetes (1.8\%), and the diet of L. forbesi includes fish (75.6\%), crustaceans (18.5\%) and cephalopods (4.4\%). 
Keywords: Life cycle; Loligo forbesi; Loligo vulgaris; Spain

\section{Introduction}

The European squid Loligo vulgaris Lamark, 1798 is one of the most common loliginid species in the northeastern Atlantic and the Mediterranean Sea. It is a neritic and semipelagic species distributed between the North Sea and the British Isles $\left(55^{\circ} \mathrm{N}\right)$ and the north African coast $\left(20^{\circ} \mathrm{N}\right)$, including the Mediterranean Sea (Worms, 1983; Roper et al., 1984; Guerra, 1992).

No specialised fishery for L. vulgaris exists in the northeastern Atlantic where it is mainly a by-catch of multi-species trawling fisheries, although seasonal artisanal fisheries using hand-line jigs exist for this species (Worms, 1983; Guerra et al., 1994).

Research into the life-cycle of L. vulgaris, from various parts of its range, has included studies from the Dutch coast (Tinbergen and Verwey, 1945), the western Mediterranean (Mangold-Wirz, 1963; Worms, 1979; Wurtz and Giuffra, 1989), the central-east Atlantic (Burukovki et al., 1979), the Moroccan coast (Baddyr, 1988), the Portuguese coast (Coelho et al., 1994; Moreno et al., 1994) and Galician waters (Guerra et al., 1992). Studies on early post embryonic development of L. vulgaris were carded out by Von Boletzky (1979) and Turk et al. (1986). Natsukari and Komine (1992) estimated the age and growth rate of this species based on statolith microstructure. Augustyn and Grant (1988) demonstrated the existence of subspecies in L. vulgaris off south-west Africa using morphometric and meristic characters, as well as isozyme electrophoresis. Finally, an overall interpretation of the life-cycle of L. vulgaris was provided by Worms (1983).

The veined squid Loligo forbesi Steenstrup, 1856 is a loliginid species of subtropical and temperate waters (it avoids temperatures below $8.5^{\circ} \mathrm{C}$ ) which occurs throughout the northeast Atlantic (20 to $60^{\circ} \mathrm{N}$, excluding the Baltic Sea), and its range extends to the Mediterranean, the Azores and the west coast of Africa, where its limits of distribution are not very well delimited (Holme, 1974; Burukovki et al., 1979; Roper et al., 1984; 
Von Boletzky and Mangold, 1985; Ragonese and Jereb, 1986; Guerra, 1992; Guerra et al., 1994; Pierce et al., 1994a).

Loligo forbesi is the only squid species fished commercially in UK waters (Pierce et al., 1994b) and in the Azores (Martins, 1982). In Portugal and in Spain it is mainly caught as by-catch in the multispecies trawling fisheries, but also artisanal fisheries exist, employing hand-jigs (Cunha and Moreno, 1994; Guerra et al., 1994).

Studies on the life cycle biology of L. forbesi have covered various part of its range, including the English Channel (Holme, 1974), the Azores (Martins, 1982; Porteiro and Martins, 1994), Faroe (Gaard, 1987), Scotland (Howard et al., 1987; Lum-Kong, 1992; Lum-Kong et al., 1992; Boyle and Ngoile, 1993a,b; Pierce et al., 1994a), the Portuguese waters (Coelho et al., 1994; Moreno et al., 1994), the Galician Sea (Guerra et al., 1992), and the western Mediterranean (Mangold-Wirz, 1963; Ragonese and Jereb, 1986). Studies of laboratory culture of L. forbesi were carried out by Hanlon et al. (1985, 1989), Porteiro and Martins (1988) and Forsythe and Hanlon (1989). Eggs and embryonic stages of this species were studied by Von Boletzky (1987a) and Segawa et al. (1988). Porteiro and Martins (1992) have encountered naturally laid eggs from L. forbesi for the first time in the Azores.

Guerra et al. (1992) reported that in Galician waters L. vulgaris could lay different batches of eggs during the span of their spawning period, which extends throughout the year, but with a breeding peak from November to May. The results obtained from the length-frequency and modal progression analysis suggested that it had a 1 year lifecycle, and almost continuous recruitment.

Results from Guerra et al. (1992), who also worked on L. forbesi in Galician waters suggested a 1 year life cycle, with a single breeding season peaking from December to February. A life span of 1 year was estimated from modal progression analysis.

The life-history strategy of short-lived species may be highly flexible and may change in response to changing environmental conditions (Coelho, 1985). However, modalprogression analysis can be misleading and it should be used in combination with age determination (Caddy, 1991). 
The present study on loliginid squids in Galician waters aims to examine aspects of population structure, reproductive biology, growth and feeding of both species in more detail, and compare the results with those obtained in other areas of their ranges.

\section{Materials and methods}

Samples of L. vulgaris and L. forbesi were obtained from commercial landings in various Galician ports (Fig. 1). They were collected from an artisanal handjig fishery and from trawl fisheries. A total of 777 L. vulgaris (14 unsexed, 351 males and 412 females) were collected from February 1991 to June 1992. In the same period, $409 \mathrm{~L}$. forbesi (26 unsexed, 248 males and 135 females) were also collected. Samples were taken on a monthly basis throughout the period.

The squids obtained in these samples were sexed and the wet body weight (BW) noted after defrosting at room temperature. The dorsal mantle length (ML) was measured to the nearest millimetre. The size range (ML) of the L. vulgaris specimens examined varied from 65 to $385 \mathrm{~mm}$ for females, and 71-475 $\mathrm{mm}$ for males, while the size range of the $\mathrm{L}$. forbesi specimens examined was $65-380 \mathrm{~mm}$ for females and 70-685 $\mathrm{mm}$ for males.

The maturity stages of males and females were assessed using a maturity scale of five stages (Boyle and Ngoile, 1993a) and gonado-somatic index. The female gonads were removed from mature (stages IV and V) animals, and length of the nidamental and accessory glands measured to the nearest millimetre. The ovary, oviducal complex and nidamental and accessory glands were weighed to the nearest $0.01 \mathrm{~g}$. The penis and the testis length were noted, and the spermatophoric complex and testis weighed. The following gonado-somatic index (GSI), was calculated for monthly samples $\mathrm{GSI}=(\mathrm{GW} / \mathrm{BW}) \times 100$ where $\mathrm{GW}$ is gonad weight and $\mathrm{BW}$ is total body weight.

Fecundity was estimated from females which were in maturity stages IV and V. Samples of the ovary and oviduct were taken from their medial parts and weighed to the nearest $0.01 \mathrm{~g}$. Subsamples (0.8-1.5 g) were obtained, fixed and stored in Gilson solution. The oocytes were released from the stroma by strong shaking in fresh water. 
The oocytes from the ovary subsamples were counted, and the number recorded for each specimen. The estimated total number of oocytes in the ovary was then calculated. The oocytes in subsamples were measured using a binocular microscope with ocular micrometer. Oocytes from the proximal oviduct subsamples were also counted, and then the total number of oocytes in the oviduct estimated. Maximum diameter of the oocytes was measured and recorded, excluding damaged oocytes. All mature individuals were analysed to determine mean size at maturity.

To analyse the length frequency distributions found in mature squids of both species the Harding method (1949) modified by Cassie (1954) was used. The data were plotted as cumulative percentage on probability paper. The points lie on an asymmetrically sigmoidal curve. The point of inflexion was used to separate the two groups involved: a group of small mature individuals and other of large mature ones. The two straight lines fitting the points representing each group were calculated using the least squares method. The size at maturity of small and large mature squid was where each straight line cuts the probability axes at $50 \%$.

Spermatophores from mature males of a range of sizes were counted, using either total counts or estimates from weighed subsamples. Lengths of a random subsamples of intact spermatophores were measured. The relationships between the total number of oocytes (ON) and body weight (BW), the total number of spermatophores (SN) and BW, and the length of the spermatophores (SL) to ML were calculated. Presence of sperm in the buccal receptacle (spermatheca) was recorded.

Statoliths were taken from all specimens. The extracted statoliths were preserved in 99.5\% ethyl alcohol until further preparation. Statoliths of L. vulgaris (84 males and 109 females) and L. forbesi (43 males and 31 females) were examined, specimens ranging from 80 to $430 \mathrm{~mm} \mathrm{ML}$ and 120-685 mm ML respectively. They were selected to cover the whole size range.

Statoliths were prepared using the method of Arkhipkin (1991) modified by Villanueva (1992). Increments were counted in the fight statolith using a video screen. Growth increments were counted from the focus to the end of the rostrum when possible, but from the focus to the lateral dome when the increments were not visible to the rostrum. 
The digestive tract was removed, and the digestive gland and the stomach contents were weighed wet. Stomach fullness was determined according to a scale of four stages $(0$, empty; 1, one-quarter full; 2, half full; 3, three-quarters full; 4, full and distended). Prey were identified to the lowest possible taxa using a reference collection of fish otoliths and cephalopod beaks, but also employing the guides by Harkönen (1986), Schmidt (1968), Bauzá-Rullán (1962), Chaine (1936) and Chaine and Duvergier (1934) for fish otoliths, Zariquiey (1968) and Gonzalez-Gurriarán and Mendez (1985) for crustacean remains, and Clarke (1986) and Perez-Gándaras (1986) for cephalopod beaks.

Seasonal differences were also analysed: winter being January-March; spring, AprilJune; summer, July-September; autumn, October-December.

\section{Results}

\subsection{Maturity stages}

Maturation in both sexes of Loligo vulgaris shows a clearly defined annual cycle. The last mature female L. vulgaris disappeared from commercial fishery landings in July (1991). Maturation of females was apparent from August (1991) onwards, as indicated by the increasing proportion of maturing (stage III) and mature (stages IV and V) squid (Fig. 2(A)). Loligo vulgaris male maturity increased from August onwards in 1991, and mature males disappeared after July 1991. A peak of maturation in both sexes was observed around February (Fig. 2(B)).

Maturation in both sexes of L. forbesi also shows a clearly defined annual cycle. Mature female L. forbesi were caught from February 1991 to May 1991. Maturation was apparent from November 1991 to April 1992, as indicated by the increasing proportion of maturing (stage III) and mature (stages IV and V) squid, (Fig. 3(A)). Mature L. forbesi males were present from February 1991 to July 1991 and male maturity increased from September 1991 to April 1992 (Fig. 3(B)).

\subsection{Gonado-somatic index}


Examination of GSI data gives a similar picture of the breeding cycle (Fig. 4). In female Loligo vulgaris GSI values were lowest in August and reached a peak in February, while the minimum and maximum values were reached 1 month earlier in males. In Loligo forbesi, males also reached peak maturity 1 month earlier than females, in December rather than in January.

\subsection{Size at maturity}

Tables 1 and 2 show the percentage of L. vulgaris and L. forbesi immature and mature individuals for each sex and size class.

Males were more precocious than females in both species. The smallest mature male of L. vulgaris was $119 \mathrm{~mm}$ ML, while the smallest mature female measured $160 \mathrm{~mm}$ ML. The size of mature animals in L. vulgaris ranged from 119 to $475 \mathrm{~mm}$ ML for males, and from 160 to $369 \mathrm{~mm}$ ML in females. The smallest mature male of L. forbesi was $122 \mathrm{~mm}$ ML, while the smallest mature female measured $160 \mathrm{~mm}$ ML. The sizes of mature L. forbesi specimens ranged from 122 to 685 mm ML for males, and from 160 to $380 \mathrm{~mm}$ ML in females.

By defining mature squid as those which have reached stages IV or V, it may be seen that two size groups of mature L. vulgaris males were found (Fig. 5 (B)). Sizes at maturity of the two male groups were $178 \mathrm{~mm}$ and $335 \mathrm{~mm}$ ML, respectively. Therefore, males mature at two different modal sizes, hence perhaps at two different ages. In females, however, this was not found (Fig. 5 (A)), but rather, the size at which $50 \%$ of females were mature was approximately 195 mm ML.

Two size groups of L. forbesi mature females and males were also found (Figs. 5 (C) and 5 (D)). Sizes at maturity for the two female groups were $176 \mathrm{~mm}$ and $308 \mathrm{~mm}$ ML, respectively. Sizes at maturity of the two male groups were $172 \mathrm{~mm}$ and $468 \mathrm{~mm} \mathrm{ML}$, respectively. Therefore, males and females mature at two different modal sizes, hence perhaps at two different ages.

\subsection{Fecundity}


Table 3 (A) shows the estimated number of oocytes in the gonad of L. vulgaris, and the size of oocytes. The estimated number of oocytes varied from 782 to 21885 . Oocytes in the distal oviduct were not found. Three size categories of oocytes were found in the ovary: large, medium and small (Table 3 (A)). These categories represented $23.0 \pm$ $17.36 \%, 13.0 \pm 7.64 \%$ and $64.0 \pm 20.6 \%$ of the total number of oocytes, respectively. The oocytes found in the proximal oviduct were almost uniform in size (Table $3(\mathrm{~A})$ ).

Table 3 (B) shows the estimated number of oocytes in each part of the gonad of L. forbesi, and the size of oocytes. The estimated number of oocytes varied from 1317 to 14956 . Oocytes in the distal oviduct were found, their diameter measured $3.13 \pm 1.08$ ram. Three size categories of oocytes were found in the ovary: large, medium and small (Table 3(B)). These categories represented $23.9 \pm 16.21 \%$, $33.1 \pm 9.6 \%$ and $43.0 \pm$ $22.8 \%$ of the total number of oocytes, respectively. The oocytes found in the proximal oviduct were almost uniform in size (Table 3(B)).

The relationship between the number of oocytes and ML in L. vulgaris and $\mathrm{L}$. forbesi is shown in Fig. 6. Females for both species showed a slight positive correlation with ML. However, some females which mature at a small size produce more oocytes than those which mature at a large size. Fecundity was not related to the timing of maturity within the span of the spawning season

\subsection{Male reproductive output}

The maximum number of spermatophores of L. vulgaris found in the spermatophoric sac were 1010 and 1000 in two males of $119 \mathrm{~mm}$ and $400 \mathrm{~mm}$ ML, respectively. The relationship between the number of spermatophores and ML was bimodal and nonlinear. Nevertheless, it seems that the number of spermatophores increases with size, but some small males were found with a similar number of spermatophores as large ones (Fig. 7 (A)).

Loligo vulgaris spermatophore length ranged from 9 to $20 \mathrm{~mm}$ but showed little variation within males. A positive linear relationship was found between the spermatophore length (SL) and ML (Fig. 8 (A)). This shows that SL increases with the 
size of the animal. The equation that expresses the relationship between SL and ML was as follows

$$
\mathrm{SL}=0.03189 \mathrm{ML}+4.5072 \quad \mathrm{r}^{2}=0.8950, \mathrm{~N}=75
$$

The relationship between the number of spermatophores (SN) and ML of L. forbesi is shown in Fig. 7(B). The maximum number of spermatophores found was 1035 in a male of $150 \mathrm{~mm}$ ML. The general trend of this relationship suggests that the larger males have fewer spermatophores than the smaller ones. Two groups of mature males could be differentiated. The first group formed by specimens from 110 to $300 \mathrm{~mm}$ ML, and the second one by males larger than $300 \mathrm{~mm}$ ML. Loligo forbesi spermatophore length ranged from 7 to $25 \mathrm{~mm}$ but showed little variation within animals. The relationship between the spermatophore length (SL) and the ML (Fig. 8(B)) shows that the length of the spermatophore increases with the size. The equation that expresses the relationship between SL and ML is as follows

$\mathrm{SL}=0.03345 \mathrm{ML}+4.6047 \quad \mathrm{r}^{2}=0.8704 \quad \mathrm{~N}=31$

The results obtained lead to the conclusion that large mature L. forbesi males produce fewer but much larger spermatophores than small mature males.

\subsection{Sex ratio}

For most of the year, the sex ratio of L. vulgaris (Table 4) was close to 1:1, with a slight predominance of females. However, the ratio rose to 3:1 females to males in December. In the total sample, there were significantly $(\mathrm{P}<0.05)$ more females than males.

The monthly sex ratio of $\mathrm{L}$. forbesi is shown in Table 4. Males were significantly more abundant than females between March and August $(\mathrm{P}<0.05)$. Females only outnumbered males in November. Taking the samples as a whole, it was observed that males outnumbered females.

\subsection{Mating}

We observed 125 mated females of L. vulgaris in the size range 140-380 mm ML. Mated females were in maturity stages II (6\%), III (57\%), IV (99\%) and V (100\%). The 
mating period appears to extend throughout the year, but only in January and February were $100 \%$ of the sampled females mated.

Twenty-eight mated females of L. forbesi were observed in the range 140-380 mm ML. Mated females were in maturity stages III (18\%), IV (100\%) and V (100\%). The mating period appears to extends throughout the year, except August and September. Mating was more intense from December to February when $89-100 \%$ of females in stages III and IV were found to have mated.

Spermatangia were always observed to be in the buccal pouches in L. vulgaris and L. forbesi females.

\subsection{Spawning season}

Four records of egg masses of L. vulgaris were collected. Three of these from the ria of Vigo (January 1992 at 30-65 m depth) hatched in the laboratory (water temperature 16$18{ }^{\circ} \mathrm{C}$ ) from January to April, producing about 1140, 6000 and 8400 hatchlings respectively. The fourth egg mass was collected in the ria of Arosa (Fig. 1), at the beginning of June 1992, at $15 \mathrm{~m}$ depth. It was formed by about 2600 eggs, and hatching occurred when it was caught.

These data and the information obtained from mating and the values of the GSI suggest that L. vulgaris spawn throughout the year, but that the period of most intensive spawning extends from December to April.

Mating data and the values of the maturity index suggest that the breeding season of $\mathrm{L}$. forbesi extends from December to May, the period of more intensive spawning extending from December to February. No egg masses of this species were collected.

Recruits of L. vulgaris (100-120 mm ML) were present throughout the year, although they represented a higher percentage of the catch in spring and autumn, while recruits of L. forbesi (80-110 mm ML) were only present in winter and spring.

\subsection{Length-weight relationship}


The relationship between ML and BW for male and female L. vulgaris can be expressed by the following.

For males

$\mathrm{BW}=0.0006779 \mathrm{ML}^{23702} \quad \mathrm{r}^{2}=0.9789, \quad \mathrm{~N}=351$

For females

$\mathrm{BW}=0.0003146 \mathrm{ML}^{2 " 5390} \quad \mathrm{r}^{2}=0.9734, \quad \mathrm{~N}=412$

The length-weight regressions for L. forbesi are as follows.

For males

$\mathrm{BW}=0.0005277 \mathrm{ML}^{24430} \quad \mathrm{r}^{2}=0.9900, \quad \mathrm{~N}=242$

For females

$0.0002889 \mathrm{ML}^{25660} \quad \mathrm{r}^{2}=0.9884, \quad \mathrm{~N}=131$

3.10. Age and growth

Fig. 9 shows the relationship between the statolith length and ML in L. vulgaris and L. forbesi, sexes considered separately. The relationship between the number of increments and ML in females and males for both species are shown in Fig. 10.

Because 193 statoliths of L. vulgaris and 74 L. forbesi statoliths have been counted, only a preliminary note can be give here. Assuming the increments form daily (Natsukari and Komine, 1992), the results illustrated in Fig. 10 suggest that: (i) similar sized individuals have different ages; (ii) growth rate varied considerably between individuals; (iii) life-span of L. vulgaris is 1 year, while L. forbesi life-span extends to 15-16 months.

\subsection{Feeding}

The degree of fullness of stomachs in both species is shown in Table 5 and the general prey composition in Table 6. The prey identified consisted of four major groups of animals: fish, crustaceans, cephalopods and polychaetes. Otoliths, lenses, fish bones, mandibles and appendages of crustaceans, cephalopod beaks, lenses and gladii, mandibles and setae of polychaetes were found. Algae and small gastropods and 
bivalves were also observed, but they were not considered as prey. Each prey item was identified to the lowest taxon. Table 7 shows the composition of the diet of L. vulgaris and L. forbesi in Galician waters.

Of the 662 stomachs of L. vulgaris examined, 235 (38.5\%) contained food or traces of food (stages 1 to 4 ), some of these (4.3\%) demonstrating a mixture of components, mainly fish and cephalopods. No feeding differences were observed between sexes ( $\mathrm{P}>$ 0.05). The composition of the diet did not vary significantly $(\mathrm{P}>0.05)$ with size.

Of the 371 stomachs of L. forbesi examined, 161 (43.8\%) contained food or traces of food (scored 1-4), some of these (10.75\%) demonstrating a mixture of components, mainly fish and cephalopods. No feeding differences were observed between sexes (P> 0.05). The composition of the diet did not vary significantly ( $\mathrm{P}>0.05)$ between 70 and $300 \mathrm{~mm}$ ML, but in the larger specimens $(\mathrm{ML}>300 \mathrm{~mm})$ it was significantly $(\mathrm{P}<0.01)$ different with respect to the smaller ones, fish being the dominant prey.

Fig. 11(A) shows the variation of the fullness index relative to ML in L. vulgaris. Only size classes with more than ten specimens were included. Stomachs with food (scores of 1-4) were grouped together. The percentage of empty stomachs was, generally, higher than that of stomachs with food. Although the frequency of stomachs with and without food was variable, no particular trend was observed. In this species, the maximum percentage of weight of the stomach contents relative to the total body weight was $5.33 \%$ (6.23 g in a male maturity stage III of $116 \mathrm{~g}$ BW). The food in the stomach was typically partially digested.

Fig. 11(B) shows the variation of the fullness index relative to ML in L. forbesi. As above, only size classes with more than ten specimens were taken into account and stomachs with food (scores of 1-4) were grouped together. The percentage of empty stomachs increased in proportion with size. In this species, the maximum percentage by weight of the stomach contents relative to the total body weight was 3.84\% (4.39 $\mathrm{g}$ in an immature male of $114 \mathrm{~g} \mathrm{BW})$.

\section{Discussion}


The results on the maturity process and the spawning season of L. vulgaris obtained in the present study are similar to those found by Mangold-Wirz (1963) and Baddyr (1988), who indicate that the species spawns throughout the year in the western Mediterranean and in the central-eastern Atlantic, and more intensively from January to October, in the western Mediterranean. Coelho et al. (1994) found that this species spawns from October to May, with a peak during November-March in the Algarve (south Portugal). Moreno et al. (1994) found that L. vulgaris spawns throughout the year, with peaks in autumn and winter in central and northern Portuguese coasts. In Galician waters, the main spawning season extends from December to April. The two reproductive phases (March-April and June-July) observed by Worms (1983) in the western Mediterranean have not been identified in the present study.

The large variation observed in the fecundity of L. vulgar\& in terms of oocytes in the ovary and oviduct, is in agreement with the observations of Baddyr (1988), who also found a wide range (1330-42 446 oocytes) at Tifnit (Morocco), although the squid in Tifnit have a greater fecundity than in Galicia. These figures also agree with Coelho et al. (1994), who found a wide range (1441-14 886 oocytes) in southern Portugal. Fecundity of this species, in terms of number of eggs produced, has been estimated by Mangold-Wirz (1963) and, in general terms, the results found in the present study (average number of eggs 4535 per egg mass) are in agreement with those found by the latter author (3000-6000 eggs per egg mass). Based on these results it seems that L. vulgaris and L. forbesi could lay different batches of eggs during the span of their breeding period.

The maximum number of spermatophores found in mature males L. vulgaris in Galicia (1010) coincides with observations by Baddyr (1988). The weak relationship found between the number of spermatophores and the size of males may be due to the fact that some individuals considered had already mated.

In L. forbesi, seasonal (winter or spring) peaks in spawning were reported in British waters (Holme, 1974; Howard et al., 1987; Boyle and Ngoile, 1993a) and off the Faroes (Gaard, 1987), but spawning nevertheless occurs at other times of the year. Holme (1974) suggested a summer spawning in the English Channel. In the Azores islands, the highest values of the gonado-somatic index (GSI) were found from December to June 
(Porteiro and Martins, 1994). Lum-Kong et al. (1992) found that spawning females were present in samples from December to June, with a peak spawning occurring in March, and that most records of egg masses were from these months. Eggs have also been found in August and September, which suggests that there is an extended spawning season in Scottish waters. Moreno et al. (1994) indicated that off the Portuguese coast, spawning takes place in autumn and winter. The results presented in this paper agree with those observed by Boyle and Ngoile (1993a) and Lum-Kong et al. (1992), who show that there is an extended spawning season for this species. The spawning peak occurs from December to February in Galicia while off Scotland and in the Azores it occurs 1 or 2 months later. No summer spawning-peak was found off the north-west Iberian peninsula.

Estimates of the fecundity of L. forbesi in the present paper agree with Boyle et al. (1994) who gives a range from 1000 to 16000 oocytes and with Boyle and Ngoile (1993a) (range 4200-17 650) in Scottish waters, and with Correia (1993) who gives 5000-32 000 oocytes in southern Portugal.

The maximum estimated number of spermatophores of L. forbesi (1035) coincides with that observed by Boyle et al. (1994) who counted 1023 spermatophores for an animal with ML of $540 \mathrm{~mm}$.

The presence of three size classes of oocytes in the ovary of the maturing and mature females of both species could be an indication of an intermittent or multiple spawning pattern, as suggested for Loligo vulgaris reynaudii (Sauer and Lipinski, 1990), in L. forbesi (Lum-Kong et al., 1992) and in other cephalopod species (Von Boletzky, 1987b, 1988; Harman et al., 1989). Changes in the ovary and testis during seasonal maturity need to be tested histologically in order to confirm this suggestion.

The presence of two peaks in maturity of L. vulgaris males at different sizes and only one peak for females agrees with the observations by Coelho et al. (1994) and Moreno et al. (1994) in Portuguese waters. Boyle et al. (1994) indicate that female and male L. forbesi mature at two different sizes in Scottish waters which is in accordance with observations of L. forbesi in the Galician Sea. This characteristic has not been observed previously. There are various possible explanations of this phenomenon. 
(1) The males maturing at a small size have slower growth rates than those maturing at a larger size, both groups being of equivalent ages.

(2) Animals maturing at a small size would be from early spawning (so that the early juveniles would live through the winter), while those maturing at a large size would be from late spawning (so that the early juveniles would live through summer). This would necessarily be reflected in the presence of two clearly marked peaks in spawning, which are not recorded in present data.

(3) Animals maturing with a large size were 2 years old, having not matured during their first year of life, which implies that there would be two life cycles, one short and one long, i.e. two reproductive cycles related to two distinct subpopulations, as proposed by Worms (1983). Our data reject this explanation, as the life cycle of this species appears to be 1 year.

(4) The two sizes represent animals migrating from various spawning areas, the difference in size being due to different growth rates, as a result of being exposed to different environmental conditions (temperature and food availability), and to different ages.

(5) Some animals mature early and then continue to grow.

It is possible that the differences between male and female abundances of both species found (sex ratio) could be due to catch bias rather than to population structure.

The presence of spermatangia in the buccal pouches in L. vulgaris and L. forbesi female suggests that mating was head-to-head (Arnold and Williams-Arnold, 1977).

The egg masses of L. vulgaris collected suggest that this species laid their eggs in sheltered bays and rias near the coast between 15 and $65 \mathrm{~m}$ depth. This agrees with observations by Mangold-Wirz (1963) and Baddyr (1988). 
The existence of microcohorts in the L. vulgaris and L. forbesi stocks was highlighted (Guerra et al., 1992) using length-frequency and modal progression analysis. Although this methodology does present problems, it can, nevertheless, prove to be a useful tool when used in conjunction with daily age reading of statoliths (Caddy, 1991).

Seasonal studies on the age and growth of L. vulgaris have been carried out using length-frequency and modal-progression analysis (Tinbergen and Verwey, 1945; Mangold-Wirz, 1963; Worms, 1979; Baddyr, 1988). These authors estimated the life span of the species to lie between 2 and 4 years. The preliminary results on growth presented in this study show a life span of about 1 year, which is in agreement with estimations by Turk et al. (1986) from a laboratory study, and Natsukari and Komine (1992) based on examining growth increments in statoliths.

Studies on the age and growth of L. forbesi have been carried out using length frequency and modal-progression analysis (Holme, 1974; Boyle and Ngoile, 1993b; Pierce et al., 1994b), examining growth increments on statoliths (Martins, 1982; Gaard, 1987; Howard et al., 1987), and in laboratory culture (Forsythe and Hanlon, 1989; Hanlon et al., 1989). Life cycle estimates from Scotland (Howard et al., 1987; Pierce et al., 1994a), England (Holme, 1974), Faroe Bank (Gaard, 1987) and the Azores (Martins, 1982) all suggest a 1 year life cycle, whereas our results from fishery data suggest a lifespan of 15-16 months.

There has still been no validation of the rate of deposition of growth increments in L. forbesi statoliths. Nevertheless, the rate has been determined in other species of loliginids (Lipinski, 1986; Yang et al., 1986; Natsukari et al., 1988), and the present authors believe that it is quite probable that $\mathrm{L}$. forbesi increments are deposited on a daily basis.

An individual variation in growth rate was also observed in four species of loliginids, Alloteuthis subulata (Lipinski, 1986), Photololigo edulis (Natsukari et al., 1988), Heterololigo bleekeri (Kinoshita, 1989), and L. vulgaris (Natsukari and Komine, 1992). The previous findings, together with the results of this study and with previous one based on modal-progression analysis (Guerra et al., 1992), suggest the existence of a considerable individual variation in the growth of loliginids. 
The preliminary data on feeding and composition of the diet of L. vulgaris and L. forbesi presented in this paper closely agree with the observations of other authors in these species (Burukovski et al., 1979; Worms, 1983; Martins, 1982; Gaard, 1987; Ngoile, 1987; Howard et al., 1987; Baddyr, 1988; Pierce et al., 1994c). A more detailed discussion about this subject can be found in Rocha et al. (1993).

The wide variety of prey eaten by both $\mathrm{L}$. vulgaris and L. forbesi is consistent with the general view of squid as opportunistic predators, taking the most readily available prey (Boyle, 1990). The predominance of fish in the diet may reflect the greater energetic profitability of feeding on fish rather than on crustaceans.

Acknowledgements

We express our gratitude to M.T. Fernandez, F. Casas, A.F. Gonzalez, M. Rasero, B. Santos and Drs. B.G. Castro and A.J. Figueras for their technical assistance and helpful criticism. The data compiling procedure arose from conversations held between the authors and P.R. Boyle, G.J. Pierce, L.C. Hastie, G. Howard, L. Coelho, H.R. Martins, M. Morhais da Cunha, A. Moreno, J. Pereira and F. Porteiro, some of whom also helped with their observations. Our thanks are also due to the people responsible in the fisherman's cooperatives, for their help in collecting the samples. This work was funded by the Commission of the European Communities within the frame of this EEC research programme in the fisheries sector (FAR, contract no. MA 1.146).

\section{References}

Arkhipkin, A.I., 1991. Method for cephalopod age and growth studies with emphasis on statolith ageing techniques. In: P. Jereb, S. Ragonese and S. von Boletzky (Editors), Squid Age Determination Using Statoliths. Proc. of the Int. Workshop held in the Istituto di Tecnologia delle Pesca e del Pescato (ITPP-CNR), Mazara del Vallo, Italy, 9-14 October 1989. Spec. Publ. No. I, N.T.R.-I.T.P.P., pp. 11-17.

Arnold, J.M. and Williams-Arnold, L.D., 1977. Cephalopoda: Decapoda. In: C.A. Giese and J.S. Pearse (Editors), Reproduction of Marine Invertebrates, Vol. IV. Molluscs: Gastropods and Cephalopods. Academic Press, New York, pp. 243-290. 
Augustyn, C.J. and Grant, W.S., 1988. Biochemical and morphological systematics of Loligo vulgaris vulgaris Lamarck and Loligo vulgaris reynaudii d'Orbigny nov. comb. (Cephalopoda: Myopsida). Malacologia, 29 (1): 215-233.

Baddyr, M., 1988. The biology of the squid Loligo vulgaris in relation to the artisanal fishing site of Tifnit, Morroco. Doctoral Thesis, Institut Agronomique et Vètèrinaire Hassan II, Rabat, 93 pp.

Bauzá-Rullán, J., 1962. Contribucion al estudio de los otolitos de los peces. Bol. R. Soc. Esp. Hist. Nat. (Biol.), 60: 5-26.

Boyle, P.R., 1990. Cephalopod biology in the fisheries context. Fish. Res., 8: 303-321. Boyle, P.R. and Ngoile, M.A.IC, 1993a. Assessment of maturity state and seasonality of reproduction in Loligo forbesi (Cephalopoda: Loliginidae) from Scottish waters. In: T. Okutani, R.K. O'Dor and T. Kubodera (Editors), Recent Advances in Fisheries Biology. Tokai University Press, Tokyo, pp. 37-48.

Boyle, P.R. and Ngoile, M.A.K., 1993b. Population variation and growth in Loligoforbesi (Cephalopoda: Loliginidae) from Scottish waters. In: T. Okutani, R.K. O'Dor and T. Kubodera (Editors), Recent Advances in Fisheries Biology. Tokai University Press, Tokyo, pp. 49-59.

Boyle, P.R., Pierce, G.J., Hastie, L.C., 1994. Flexible reproductive strategies in the squid Loligo forbesi. J. Mar. Biol. Assoc. UK, in press.

Burukovski, R.N., Gaevskaya, A.V., Domanevski, L.N., Nigmatullin, Ch. and Panfilov, B.G., 1979. Main results of researchs on squids carried out by the AtlantNIRO in the central-east Atlantic. I.C.E.S. 1979/K: 2.

Caddy, J.F., 1991. Daily rings on squid statoliths: an opportunity to test standard population modals? In: P. Jereb, S. Ragonese and S. von Boletzky (Editors), Squid Age Determination using Statoliths. Proc. of the Int. Workshop, Istituto di Tecnologia delle Pesca e del Pescato (ITPP-CNR), Mazara del Vallo, Italy, 9-14 October 1989. Spec. Publ. No. 1, N.T.R.-I.T.P.P., Mazara del Vallo, pp. 53-66.

Cassie, R.M., 1954. Some use of probability paper in the analysis of size frequency distribution. Aust. J. Mar. Freshwater Res., 5: 513-522.

Chaine, J., 1936. Recherches sur les otolithes des poissons. Etude descriptive et comparative de la Sagitta des Téléostrens (3eme partie). E. Drovillard (Editor). Ext. Act. Soc. Linnéene Bordeaux, 88: 262 pp. 
Chaine, J. and Duvergier, J., 1934. Recherches sur les otolithes des poissons. Etude descriptive et comparative de la Sagitta des Téléostrens. E. Drovillard (Editor), Ext. Act. Soc. Linnéene Bordeaux, 86: 242 pp.

Clarke, M.R. (Editor), 1986. A Handbook for the Identification of Cephalopods Beaks. Clarendon Press, Oxford, pp. 273.

Coelho, M.L., 1985. Review of the influence of oceanographic factors on cephalopod distribution and life cycles. NAFO Sci. Counc. Stud., 9: 47-57.

Coelho, M.L., Quintela, J., Bettencourt, V., Matto Silva, G. and Villa, H., 1994. Population structure, maturation pattern and fecundity of the squid Loligo vulgaris from southern Portugal. Fish, Res., 21: 87-102.

Correia, V.M., 1993. Fecundidade na especie Loligo forbesi (Stenstrup, 1856). Relatorio de Estagio de Licenciatura em Biologia Marinha e Pescas. Universidade do Algarve, Faro, Portugal, 51 pp.

Cunha, M.M. and Moreno, A., 1994. Recent trends in the Portuguese squid fishery. Fish. Res., 21: 231-241.

Forsythe, J.W. and Hanlon, R.T., 1989. Growth of the Eastern Atlantic squid, Loligo forbesi Steenstrup (Mollusca: Cephalopoda). Aquat. Fish. Manage., 20: 1-14.

Gaard, E., 1987. An investigation of the squid Loligo forbesi Steenstrup on Faroe Bank. I.C.E.S. 1987/K: 18.

Gonzalez-Gurriarán, E. and Mendez, M., 1985. Crustáceos decápodos de las costas de Galicia I. Brachyura. Cuadernos de Area de Ciencias Biologicas. Sem. Est. Gal. Ed. do Castro. A. Coruña, Vol. 2, 242 pp.

Guerra, A., 1992. Mollusca, Cephalopoda. In: M.A. Ramos et al. (Editors), Fauna Iberica, Vol. 1. Museo Nacional de Ciencias Naturales. CSIC, Madrid, 327 pp.

Guerra, A., Rocha, F., Casas, F. and Fernandez, M.T., 1992. Loligo vulgaris and Loligo forbesi (Cephalopoda, Loliginidae): their present status in Galician Fisheries. I.C.E.S.C.M. 1992/K: 40.

Guerra, A., Sanchez, F. and Rocha, F., 1994. The Spanish fishery for Loligo: recent trends. Fish. Res., 21: 217-230

Hanlon, R.T., Hixon, R.F., Turk, P.E., Lee, P.G. and Yang, W.T., 1985. Behavior, feeding and growth of young Loligoforbesi (Cephalopoda: Myopsida) reared in the laboratory. Vie Milieu, 35 (3/4): 247. 
Hanlon, R.T., Yang, W.T., Turk, P.E., Lee, P.G. and Hixon, R.F., 1989. Laboratory culture and estimated life span of the Eastern Atlantic squid, Loligo forbesi Steenstrup, 1856 (Mollusca: Cephalopoda). Aquat. Fish. Manage., 20: 15-34.

Harding, T.P., 1949. The use of probability paper for the graphical analysis of polymodal frequency distributions. J. Mar. Biol. Assoc. UK, 28:141-153.

Harkönen, T., 1986. Guide of the otoliths of the fishes of the Northeast Atlantic. Danbin Ap. 5, Sweden, 256 pp.

Harman, R.F., Young, R.E., Mangold, K.M., Siuzuki, T. and Hixon, R.F., 1989. Evidence for multiple spawning in the tropical oceanic squid Sthenoteuthis oualaniensis (Teuthoidea: Ommastrephidae). Mar. Biol., 101: 513-519.

Holme, N.A., 1974. The biology of Loligo forbesi Steenstrup (Mollusca: Cephalopoda) in the Plymouth area. J. Mar. Biol. Assoc. UK, 54: 481-503.

Howard, F.G., Ngoile, M.A. and Mason, J., 1987. Loligo forbesi: Its present status in Scottish fisheries. I.C.E.S. 1987/K: 5.

Kinoshita, T., 1989. Age and growth of loliginid squid, Heterololigo bleekeri. Bull. Sei Kai Reg. Fish. Res. Lab. (Nagasaki, Japan), 67: 59-68.

Lipinski, M., 1986. Methods for the validation of squid age from statoliths. J. Mar. Biol. Assoc. UK, 66: 505-526.

Lum-Kong, A., 1992. A histological study of the accessory reproductive organs of female Loligo forbesi (Cephalopoda: Loliginidae). J. Zool. London, 226: 469-490.

Lum-Kong, A., Pierce, G.J. and Yau, C., 1992. Timing of spawning and recruitment in Loligo forbesi (Cephalopoda: Loliginidae) in Scottish waters. J. Mar. Biol. Assoc. UK, 72: 301-311.

Mangold-Wirz, K., 1963. Biologic des Cephalopodes bentiques et nectoniques de la Mer Catalane. Vie Milieu, 13 (Suppl.): 285.

Martins, H.R., 1982. Biological studies of the exploited stock of Loligo forbesi (Mollusca: Cephalopoda) in the Azores. J. Mar. Biol. Assoc. UK, 62: 799-808. Moreno, A., Cunha, M.M. and Pereira, J.M.F., 1994. Population biology of veined squid (Loligo forbesi) and European squid (Loligo vulgaris) from the Portuguese coast. Fish. Res., 21: 71-86.

Natsukari, Y. and Komine, N., 1992. Age and growth estimation of the European squid, Loligo vulgaris, based on statolith microstructure. J. Mar. Biol. Assoc. UK, 72:271280. 
Natsukari, Y., Nakanose, T. and Oda, K., 1988. Age and growth of loliginid Photololigo edulis (Hoyle, 1885). J. Exp. Mar. Biol. Ecol., 116: 177-190.

Ngoile, M.A.K., 1987. Fishery biology of the squid Loligo forbesi (Cephalopoda: Loliginidae) in Scottish waters. Ph.D. Thesis, University of Aberdeen, 218 pp.

Pérez-Gándaras, G., 1986. Estudio de los Cefalopodos Ibericos: Sistemática y bionomia mediante el estudio morfometrico comparado de sus mandibulas. Tesis Doctoral 37/86, Universidad Complutense de Madrid, 350 pp.

Pierce, G.J., Boyle, P.R., Hastie, L.C. and Key, L., 1994a. The life history of Loligo forbesi (Cephalopoda: Loliginidae) in Scottish waters. Fish. Res., 21: 17-41.

Pierce, G.J., Boyle, P.R., Hastie, L.C. and Shanks, A., 1994b. Distribution and abundance of the fished population of Loligo forbesi in UK waters: analysis of fishery data. Fish. Res., 21: 193-216.

Pierce, G.J., Hastie, L.C., Boyle, P.R. and Santos, B., 1994c. Diets of squid Loligo forbesi and Loligo vulgaris in the northeast Atlantic. Fish. Res., 21: 149-163.

Porteiro, F.M. and Martins, H.R., 1992. First finding of natural laid eggs from Loligo forbesi Steenstrup, 1856 (Mollusca: Cephalopoda) in the Azores. Arquipie1ago. Life Earth Sci., 10:119-120.

Porteiro, F.M. and Martins, H.R., 1994. Population biology of Loligo forbesi Steenstrup, 1856 (Mollusca: Cephalopoda) in the Azores: sample composition and maturation of squid caught by jigging. Fish. Res., 21:103-114.

Porteiro, F.M., Martins, H.R. and Hanlon, R.T., 1990. Some observations on the behaviour of adult squids, Loligo forbesi, in captivity. J. Mar. Biol. Assoc. UK, 70: 459-472.

Ragonese, S. and Jereb, P., 1986. Loligo forbesi Steenstrup 1856 (Cephalopoda: Loliginidae) nel versante siciliano del Mare Pelagico (Canale di Sicilia): nota preliminare sulla distribuzione, composizione per taglia e biologia riproduttiva. Nova Thalassia, 8 (3): 529-535.

Rocha, F., Castro, B.G., Gil, M.S. and Guerra, A., 1993. The diets of Loligo vulgaris and Loligo forbesi (Cephalopoda: Loliginidae) in the Galician waters (NW Spain). I.C.E.S. 1993/K: 15.

Roper, C.F.R., Sweeney, M.J. and Nauen, C.E., 1984. FAO species catalogue. Vol. 3. Cephalopods of the world. An annotated and illustrated catalogue of species of interest to fisheries. Fish. Synopsis 125, Vol. 3, FAO, Rome, 277 pp. 
Sauer, W.H. and Lipinski, M.R., 1990. Histological validation of morphological stages of sexual maturity in Chokker Squid Loligo vulgaris reynaudii D'Orb (Cephalopoda: Loliginidae). S. Afr. J. Mar. Sci., 9: 189-200.

Segawa, S., Yang, W.T., Marthy, H.J. and Hanlon, R.T., 1988. Illustrated embryonic stages of the eastern Atlantic squid Loligo forbesi. The Veliger, 30 (3): 230-243.

Schmidt, W., 1968. Verleichend morphologische studie fiber die otolithen mariner knochenfische. Arch. Fisch. Wiss., 19(1): 96 pp.

Tinbergen, L. and Verwey, J., 1945. Zur Biologie von Loligo vulgaris Lam. Arch. Néerl. Zool., 7(1-2): 213-286.

Turk, P.E., Hanlon, R.T., Bradford, L.A. and Yang, W.T., 1986. Aspects of feeding, growth and survival of the European squid Loligo vulgaris Lamarck, 1799, reared through the early growth stages. Vie Milieu, 36(1): 9-13.

Villanueva, R., 1992. Interannual growth differences in the oceanic squid Todarodes angolensis Adam in the northern Benguela upwelling system, based on statoliths growth increment analysis. J. Exp. Mar. Biol. Ecol., 159: 157-177.

Von Boletzky, S., 1979. Observations on early post-embryonic development of Loligo vulgaris (Mollusca, Cephalopoda). Rapp. Comm. Int. Mer Medit., 25/26 (10): 155158.

Von Boletzky, S., 1987a. On egg and capsule dimensions in Loligo forbesi (Mollusca: Cephalopoda): A note. Vie Milieu, 37(3/4): 187-192.

Von Boletzky, S., 1987b. Fecundity variation in relation to intermittent or chronic spawning in the cuttlefish, Sepia officinalis L. (Mollusca, Cephalopoda). Bull. Mar. Sci., 40 (2): 382-387.

Von Boletzky, S., 1988. A new record of long-continued spawning in Sepia officinalis (Mollusca, Cephalopoda). Rapp. Comm. int. Mer Medit., 31 (2): 257.

Von Boletzky, S. and Mangold, K., 1985. Loligo forbesi in the north-western Mediterranean (Mollusca: Cephalopoda). Rapp. Comm. Int. Mer Medit., 29 (8): 245-246.

Worms, J., 1979. L'utilisation des prises commerciales en biologie des pêches. Application à l'étude d'une population de Loligo vulgaris (Cephalopoda, Teuthoidea) du Golfe du Lion. These 3ème cycle. USTL Montpellier, France, 197 pp.

Worms, J., 1983. Loligo vulgaris. In: P.R. Boyle (Editor), Cephalopod Life Cycles, Vol. 1. Species Accounts. Academic Press, London, pp. 143-157. 
Wurtz, M. and Giuffra, E., 1989. Reproduzione e accrescimento di Loligo vulgaris (Cephalopoda, Myopsida) in Mar Ligure. Oebalia, Vol. XV-2, N.S., pp. 831-834.

Yang, W.T., Hixon, R.F., Turk, P.E., Krejci, M.E., Hulet, W.H. and Hanlon, R.T., 1986.

Growth behaviour and sexual maturation of the market squid, Loligo opalescens, cultured through the life cycle. Fish. Bull. US, 84: 771-798.

Zariquiey, R., 1968. Crustaceos Decapodos Ibericos. Invest. Pesq., 32:1-510. 
Fig. 1. Study area (Galician coast, northeastern Atlantic), showing the harbours where Loligo spp. samples were landed.

Fig. 2. Monthly percentages of each maturity stage (I-V) for Loligo vulgaris females (A) and males (a).

Fig. 3. Monthly percentages of the maturity stages (I-V) for Loligo forbesi females (A) and males (B).

Fig. 4. Monthly values and standard deviation of the gonado-somatic index for L. vulgaris females (A) and males (B) and for L. forbesi females (C) and males (D).

Fig. 5. Cumulative percentage of L. vulgaris and L. forbesi females and males mature at each size (ML). The point of inflexion on the sigmoidal curves indicates that two group of mature individual can be differentiated. The two straight lines represent each group on probability paper. The size at maturity of small and large mature squid is when each straight line cut the probability axis at $50 \%$.

Fig. 6. Relationship between size (ML) and fecundity (number of oocytes) for mature females of Loligo vulgaris (A) and Loligo forbesi (B).

Fig. 7. Relationship between size (ML) and number of spermatophores for mature males of Loligo vulgaris (A) and Loligo forbesi (B).

Fig. 8. Relationship between ML and spermatophore length in mature males of (A) Loligo vulgaris and (B) Loligo forbesi.

Fig. 9. Relationship between ML and statolith length of Loligo vulgaris females (A) and males (B) and Loligo forbesi females (C) and males (D).

Fig. 10. Relationship between ML and the number of growth increments in Loligo vulgaris females (A) and males (B) and Loligo forbesi females (C) and males (D). 
Fig. 11. Relationship between ML and fullness index of the stomach in Loligo vulgaris and Loligo forbesi. 0, empty stomach; 1-4, stomachs with traces of food content, and/or full to the point of being distended.

Table 1

Percentage of Loligo vulgaris males and females in each maturity stage for each $20 \mathrm{~mm}$ size class

\begin{tabular}{|c|c|c|c|c|c|c|}
\hline \multirow{2}{*}{$\begin{array}{l}\text { Size } \\
\text { class }\end{array}$} & \multicolumn{3}{|c|}{ Males } & \multicolumn{3}{|c|}{ Females } \\
\hline & $\begin{array}{l}\text { Total } \\
\text { no. }\end{array}$ & $\begin{array}{l}\text { Proportion } \\
\text { immature }\end{array}$ & $\begin{array}{l}\text { Proportion } \\
\text { mature }\end{array}$ & $\begin{array}{l}\text { Total } \\
\text { no. }\end{array}$ & $\begin{array}{l}\text { Proportion } \\
\text { immature }\end{array}$ & $\begin{array}{l}\text { Proportion } \\
\text { mature }\end{array}$ \\
\hline $81 / 100$ & 3 & 100.00 & & 6 & 100.00 & \\
\hline $101 / 120$ & 21 & 95.24 & 4.76 & 12 & 100.00 & \\
\hline $121 / 140$ & 31 & 96.77 & 3.23 & 37 & 100.00 & \\
\hline $141 / 160$ & 34 & 88.24 & 11.76 & 60 & 98.33 & 1.67 \\
\hline $161 / 180$ & 53 & 86.79 & 13.21 & 90 & 82.22 & 17.78 \\
\hline $181 / 200$ & 33 & 69.70 & 30.30 & 77 & 76.62 & 23.38 \\
\hline $201 / 220$ & 41 & 90.24 & 9.76 & 58 & 68.97 & 31.03 \\
\hline $221 / 240$ & 33 & 72.73 & 27.27 & 27 & 66.67 & 33.33 \\
\hline $241 / 260$ & 27 & 81.48 & 18.52 & 23 & 34.78 & 65.22 \\
\hline $261 / 280$ & 13 & 92.31 & 7.69 & 9 & 77.78 & 22.22 \\
\hline $281 / 300$ & 19 & 47.37 & 52.63 & 7 & 57.14 & 42.86 \\
\hline $301 / 320$ & 17 & 47.06 & 52.94 & 10 & 60.00 & 40.00 \\
\hline $321 / 340$ & 4 & 25.00 & 75.00 & 6 & 66.67 & 33.33 \\
\hline $341 / 360$ & 12 & 8.33 & 91.67 & 3 & 66.67 & 33.33 \\
\hline $361 / 380$ & 5 & & 100.00 & 1 & & 100.00 \\
\hline $381 / 400$ & 8 & 25.00 & 75.00 & & & \\
\hline $401 / 420$ & 7 & & 100.00 & & & \\
\hline $421 / 440$ & 3 & & 100.00 & & & \\
\hline $441 / 460$ & 2 & & 100.00 & & & \\
\hline $461 / 480$ & 1 & & 100.00 & & & \\
\hline Total & 368 & & & 426 & & \\
\hline
\end{tabular}

Table 2 
Percentage of Loligo forbesi males and females in each maturity stage for each $20 \mathrm{~mm}$ size class

\begin{tabular}{|c|c|c|c|c|c|c|}
\hline \multirow[t]{2}{*}{ Size class } & \multicolumn{3}{|l|}{ Males } & \multicolumn{3}{|l|}{ Females } \\
\hline & Total no. & $\begin{array}{l}\text { Proportion } \\
\text { immaturate }\end{array}$ & $\begin{array}{l}\text { Proportion } \\
\text { mature }\end{array}$ & Total no. & $\begin{array}{l}\text { Proportion } \\
\text { immaturate }\end{array}$ & $\begin{array}{l}\text { Proportion } \\
\text { mature }\end{array}$ \\
\hline $81 / 100$ & 4 & 100.00 & & 8 & 100.00 & \\
\hline $101 / 120$ & 8 & 100.00 & & 12 & 100.00 & \\
\hline $121 / 140$ & 29 & 96.55 & 3.45 & 19 & 100.00 & \\
\hline $141 / 160$ & 34 & 79.41 & 20.59 & 11 & 90.91 & 9.09 \\
\hline $161 / 180$ & 36 & 88.89 & 11.11 & 12 & 66.67 & 33.33 \\
\hline $181 / 200$ & 6 & 100.00 & & 5 & 60.00 & 40.00 \\
\hline $201 / 220$ & 12 & 83.33 & 16.67 & 10 & 90.00 & 10.00 \\
\hline $221 / 240$ & 14 & 100.00 & & 11 & 81.82 & 18.18 \\
\hline $241 / 260$ & 13 & 84.62 & 15.38 & 11 & 81.82 & 18.18 \\
\hline $261 / 280$ & 16 & 87.50 & 12.50 & 8 & 100.00 & \\
\hline $281 / 300$ & 15 & 93.33 & 6.67 & 11 & 81.82 & 18.18 \\
\hline $301 / 320$ & 18 & 100.00 & & 7 & 42.86 & 57.14 \\
\hline $321 / 340$ & 10 & 100.00 & & 3 & 33.33 & 66.67 \\
\hline $341 / 360$ & 9 & 100.00 & & 2 & & 100.00 \\
\hline $361 / 380$ & 4 & 100.00 & & 2 & & 100.00 \\
\hline $381 / 400$ & 3 & 66.67 & 33.33 & & & \\
\hline $401 / 420$ & 2 & & 100.00 & & & \\
\hline $441 / 460$ & 4 & 25.00 & 75.00 & & & \\
\hline $461 / 480$ & 3 & & 100.00 & & & \\
\hline $481 / 500$ & 2 & 50.00 & 50.00 & & & \\
\hline $501 / 520$ & 1 & & 100.00 & & & \\
\hline $521 / 540$ & 1 & & 100.00 & & & \\
\hline $541 / 560$ & 1 & & 100.00 & & & \\
\hline $621 / 640$ & 1 & & 100.00 & & & \\
\hline $681 / 700$ & 1 & & 100.00 & & & \\
\hline Total & 247 & & & 132 & & \\
\hline
\end{tabular}

Table 3 
Estimated number of oocytes in ovaries of female Loligo vulgaris and Loligo forbesi at Stage IV of maturity. Size of the oocytes in the ovary (OSO) and in the proximal oviduct (OSPO)

\begin{tabular}{|c|c|c|c|c|c|c|c|c|c|c|c|}
\hline & \multicolumn{3}{|c|}{ Number } & \multicolumn{6}{|c|}{ OSO } & \multicolumn{2}{|c|}{ OSPO } \\
\hline & Max & Min & $\mathrm{N}$ & $\mathrm{m}$ & SD & $\mathrm{m}$ & SD & $\mathrm{m}$ & SD & $\mathrm{m}$ & $\mathrm{SD}$ \\
\hline (a) Loligo & 21885 & 782 & 74 & 2.47 & 0.19 & 1.50 & 1.12 & 0.84 & 0.15 & 2.74 & 1.54 \\
\hline vulgaris & & & & & & & & & & & \\
\hline (b) Loligo & 14956 & 1317 & 43 & 2.87 & 0.23 & 1.74 & 0.21 & 0.80 & 0.14 & 3.06 & 0.28 \\
\hline forbesi & & & & & & & & & & & \\
\hline
\end{tabular}

Max, maximum; Min, minimum; N, number of specimens; m, mean; SD, standard deviation.

Table 4

Loligo vulgaris and Loligo forbesi sex ratio

\begin{tabular}{|c|c|c|c|c|c|c|c|c|}
\hline \multirow[t]{2}{*}{ Date } & \multicolumn{3}{|c|}{ Loligo vulgaris } & \multicolumn{3}{|c|}{ Loligo forbesi } & & \\
\hline & $\mathrm{M}$ & $\mathrm{F}$ & $\mathrm{U}$ & $\mathrm{M}$ & $\mathrm{F}$ & $\mathrm{U}$ & & \\
\hline $2 / 1991$ & & & & & 11 & 10 & - & NS \\
\hline 3/1991 & & & & & 18 & 2 & - & $*$ \\
\hline 4/1991 & 25 & 21 & 1 & NS & 5 & 3 & - & NS \\
\hline $5 / 1991$ & & & & & 6 & 3 & - & NS \\
\hline 6/1991 & 21 & 18 & 2 & NS & & & & \\
\hline 7/1991 & 11 & 5 & - & NS & 30 & 4 & - & $*$ \\
\hline 8/1991 & 32 & 30 & 1 & NS & 40 & 9 & - & $*$ \\
\hline 9/1991 & 44 & 50 & 7 & NS & 16 & 17 & - & NS \\
\hline 10/1991 & 45 & 41 & 3 & NS & 15 & 7 & - & NS \\
\hline 11/1991 & 40 & 54 & - & NS & 4 & 12 & - & $*$ \\
\hline 12/1991 & 22 & 73 & - & * & 1 & 1 & - & NS \\
\hline $1 / 1992$ & 21 & 32 & - & NS & 8 & 8 & 9 & NS \\
\hline 2/1992 & 2 & 3 & - & NS & 6 & 5 & - & NS \\
\hline 3/1992 & 18 & 8 & - & NS & 18 & 21 & 10 & NS \\
\hline 4/1992 & 35 & 21 & - & NS & 48 & 21 & 7 & $*$ \\
\hline 5/1992 & & & & & 12 & 3 & - & $*$ \\
\hline 6/1992 & 36 & 55 & - & $*$ & 10 & 9 & - & NS \\
\hline
\end{tabular}




\begin{tabular}{lllllllll}
\hline Total & 352 & 411 & 14 & $*$ & 248 & 135 & 26 & $*$
\end{tabular}

M, males; F, females; U, unsexed.

$* \mathrm{P}<0.05$; NS, not significant.

Table 5

Distribution (as a percentage) of the degree of stomach fullness (DF) of Loligo vulgaris and Loligo forbesi

\begin{tabular}{lllllll}
\hline & $\mathrm{n}$ & \multicolumn{5}{l}{$\mathrm{DF}^{\mathrm{a}}$} \\
\cline { 3 - 7 } & & 0 & 1 & 2 & 3 & 4 \\
\hline Loligo vulgaris & 662 & 61.5 & 8.9 & 7.7 & 10.9 & 11.0 \\
Loligo forbesi & 371 & 56.6 & 12.1 & 7.0 & 13.5 & 10.8 \\
\hline
\end{tabular}

${ }^{\text {a }} 0$, empty; 1 , up to one-quarter full; 2 , one-quarter to one-half full; 3 , one-half full to full; 4, distended.

Table 6

Prey composition (as a percentage) of stomachs with food contents in Loligo vulgaris and Loligo forbesi

\begin{tabular}{lll}
\hline & Loligo vulgaris & Loligo forbesi \\
\hline Fish & 86.8 & 75.6 \\
Cephalopoda & 6.0 & 4.4 \\
Crustacea & 3.0 & 18.5 \\
Polychaeta & 1.8 & - \\
Others (Algea + Ascidians) & 2.4 & 1.5 \\
\hline
\end{tabular}

Table 7

Preyite ms found in gastric contents of Loligo vulgaris and Loligo forbesi in Galician waters
L. vulgaris L. forbesi

Teleosteans

Clupeid

Sardina pichardus

\begin{tabular}{ll}
$X$ & - \\
- & $X$ \\
\hline
\end{tabular}




\begin{tabular}{|c|c|c|}
\hline Sprattus sprattus & $\mathrm{X}$ & - \\
\hline Argentina sphyraena & $\mathrm{X}$ & $\mathrm{X}$ \\
\hline Merluccius merluccius & - & $\mathrm{X}$ \\
\hline Gadid & $\mathrm{X}$ & $\mathrm{X}$ \\
\hline Micromesistius poutassou & $\mathrm{X}$ & $\mathrm{X}$ \\
\hline Gadiculus argenteus & $\mathrm{X}$ & - \\
\hline Trisopterus sp. & & $\mathrm{X}$ \\
\hline Cepola macrophtalma & $X$ & $\mathrm{X}$ \\
\hline Trachurus trachurus & $\mathrm{X}$ & $\mathrm{X}$ \\
\hline Ammodytid & $\mathrm{X}$ & $\mathrm{X}$ \\
\hline Gymnammodytes semisquamatus & $\mathrm{X}$ & $\mathrm{X}$ \\
\hline Ammodytes tobianus & $\mathrm{X}$ & - \\
\hline Hyperoplus lanceolatus & $\mathrm{X}$ & - \\
\hline Gobiid & $\mathrm{X}$ & $\mathrm{X}$ \\
\hline Aphia minuta & $\mathrm{X}$ & $\mathrm{X}$ \\
\hline Pomatoschistus sp. & - & $\mathrm{X}$ \\
\hline Pomatoschitus minutus & - & $X$ \\
\hline Crystalogobius sp. & - & $\mathrm{X}$ \\
\hline Gobiusculus flavescens & $\mathrm{X}$ & - \\
\hline Callionymus sp. & $\mathrm{X}$ & $\mathrm{X}$ \\
\hline Callionymus so. lyra & - & $\mathrm{X}$ \\
\hline Callionymus lyra & - & $\mathrm{X}$ \\
\hline Callionymus reticulatus & $X$ & - \\
\hline Blennius sp. & $\mathrm{X}$ & - \\
\hline Blennius ocellaris & $\mathrm{X}$ & - \\
\hline Atherina sp. & $\mathrm{X}$ & $\mathrm{X}$ \\
\hline Ahterina presbyter & $\mathrm{X}$ & - \\
\hline Flat fish & $X$ & - \\
\hline Unidentified fish & $\mathrm{X}$ & $\mathrm{X}$ \\
\hline \multicolumn{3}{|l|}{ Crustaceans } \\
\hline Macrura Natantia & $\mathrm{X}$ & - \\
\hline Processidae & - & $\mathrm{X}$ \\
\hline Hippolidae & - & $\mathrm{X}$ \\
\hline
\end{tabular}




\begin{tabular}{lll}
\hline Caridea & - & $\mathrm{X}$ \\
Brachyura & - & $\mathrm{X}$ \\
Brachyura, Portunidae & $\mathrm{X}$ & - \\
Misidacean & $\mathrm{X}$ & $\mathrm{X}$ \\
Euphausiacean & - & $\mathrm{X}$ \\
Copepoda Calanoidea & - & $\mathrm{X}$ \\
Pelagic crustacean & $\mathrm{X}$ & - \\
Unidentified crustacean & $\mathrm{X}$ & $\mathrm{X}$ \\
Molluscs & & \\
Turritella sp. & $\mathrm{X}$ & - \\
Bivalve & $\mathrm{X}$ & $\mathrm{X}$ \\
Rondeletiola minor & $\mathrm{X}$ & - \\
Sepietta sp. & $\mathrm{X}$ & - \\
Mollucs & & $\mathrm{X}$ \\
Loligo sp. & $\mathrm{X}$ & $\mathrm{X}$ \\
Loligo forbesi & $\mathrm{X}$ & $\mathrm{X}$ \\
Loligo vulgaris & $\mathrm{X}$ & $\mathrm{X}$ \\
Alloteuthis sp. (subulata?) & - & $\mathrm{X}$ \\
Alloteuthis subulata & - & $\mathrm{X}$ \\
Octopus vulgaris & & \\
Eledone cirrhosa & & $\mathrm{X}$ \\
Unidentified cephalopods & $\mathrm{X}$ \\
Polychaeta & $\mathrm{X}$ \\
Polychaetes & $\mathrm{X}$ \\
Nereis divesicolor & $\mathrm{X}$ \\
\hline Algae & & \\
\hline
\end{tabular}

